\title{
ANALISIS PENERAPAN MODEL DAN METODE PEMBELAJARAN TEPAT GUNA PADA DAERAH 3T (TERDEPAN,TERPENCIL DAN TERTINGGAL) DI KABUPATEN MAHAKAM ULU
}

\author{
Muhammad Tommy Fimi Putra ${ }^{1)}$, Arianti' ${ }^{2}$, dan Elbadiansyah ${ }^{3)}$ \\ 1,2,3 ProgramStudi Pendidikan Ekonomi, Fakultas Ilmu Pendidikan Pengetahuan Sosial, IKIP PGRI Kalimantan Timur \\ 1,2,3Jl.Swandi Blok C RT.23 Kota Samarinda, 75123 \\ E-mail: Tommy.fimi@gmail.com ${ }^{1)}$, ayiezawibisono@gmail.com²), Mr.Elbadiansyah@yahoo.com ${ }^{3)}$
}

\begin{abstract}
ABSTRAK
Keadaan pendidikan wilayah Kabupaten Mahakam Ulu merupakan permasalah yang umum terjadi pada wilayah kepedalaman khususnya di hutan Kailmantan dimana wilayah yang cukup terisolir hanya dapat melalui jalur sungai karena belum ada jalur darat yang layak dapat menuju ke lokasi tersebut. Dalam Penelitian ini bertujuan untuk meningkatkan kualitas pendidikan dan menjadi solusi dalam mengatasi kesulitan dalam tenaga pendidikan berkualitas dengan menggunakan model dan metode tepat guna pada pembelajaran disekolah. Pada Metodelogi Penelitian menggunakan Metode Tindakan Kelas (PTK), Dari hasil penelitian pada sekolah Dasar Negeri 1 (SDN 1) Ujoh Bilang Kelas VI dengan model Pembelajaran Koperatif dan metode Penemuan sangat tepat untuk di terapkan, pada Sekolah Menengah Pertama Negeri 1 (SMPN 1) Ujoh Bilang Kelas VII model Pembelajaran Koperatif dan metode demontrasi tepat untuk diterapkan di SMP sedangkan model Pembelajaran Koperatif dan metode Ekspositori pada Sekolah Menengah Pertama Negri (SMAN 1) Ujoh Bilang Kelas Kelas X juga sangat tepat untuk di terapkan di Sekolah Menengah Pertama Negri (SMAN 1) Ujoh Bilang Kelas Kelas X, Hasil Penelitian ini menujukan bahwa tingkat pendidikan pada wilayah $3 \mathrm{~T}$ dapat meningkat atau sama dengan sekolah di wilayah perkotaan khususnya jika memaksimalkan metode dan model pembelajaran tersebut dengan media sarana dan prasarana yang lengkap dan memadai.
\end{abstract}

Kata Kunci : Mutu Pendidikan, Forum, Pembelajaran Tepat Guna, Mahakam Ulu

\section{PENDAhUluan}

Dalam Pendidikan nasional memiliki tujuan utama yaitu mencerdaskan kehidupan bangsa yang tertuang dalam pembukaan UUD'45 selain itu pendidikan yang berkualitas harus setara di semua wilayah di Indonesia. Tak terkecuali pada Kabupaten Mahakam Ulu yang merupakan daerah yang cukup terisolir dari wilayah perkotaan dan merupkan daerah yang berbatasan langsung dengan Malaysia, selain itu juga termasuk dalam wilayah 3T (Terdepan, Terpencil dan Tertinggal).

Pendidikan yang berada pada wilayah Kabupaten Mahakam Ulu di ketahui masih menjadi permasalah yang mendasar dan sangat penting untuk di teliti terutama dimana harapan pemerintah pusat menginginkan pemerataan pendidikan yang sama baik diperkotaan maupun di wilayah pedalaman akan tetapi permasalahan yang dihadapai pada wilayah Kabupaten Mahakam Ulu sangat amat memprihatinkan terutama pada sarana dan prasarana yang masih kurang layak, kemampuan Sumber Daya Manusia (SDM) khususnya tenaga pendidik yang tergolong masih minim selain itu penerapan pembelajaran yang sangat terbatas hanya model dan metode ceramah saja tanpa ada model dan metode penerapan-penerapan lainya sehingga menjadikan pendidikan diwilayah tersebut sangat sulit untuk menyamakan pendidikan yang berada pada wilayah perkotaan.
Sejalan dengan pemikiran (Anugraheni, 2019) yang menyatakan bahwa Kualitas pendidikan ditentukan oleh beberapa faktor kurikulum, guru atau tenaga pengajar, fasilitas, dan sumber belajar. Guru mempunyai peranan penting dalam meningkatkan kualitas pembelajaran di dalam kelas. Untuk meningkatkan kualitas pembelajaran, guru dapat melakukan pembelajaran yang inovatif di dalam kelas. Pembelajaran inovatif mengutamakan siswa sebagi pusat pembelajaran.Menurut (Usep, 2016) Pembelajaran secara komprehensif merupakan langkah implementasi dari rencana pembelajaran terpadu secara menyeluruh, berisi rincian dari prosedur pembelajaran.

Selain itu menurut (Intan, 2014) Pendidikan sebagai suatu sistem yang merupakan satu kesatuan yang utuh, dengan bagian-bagiannya yang berinteraksi satu sama lain. Pendidikan dapat diartikan sebagai satu keseluruhan karya insani yang terbentuk dari bagian-bagian yang mempunyai hubungan fungsional dalam usaha mencapai tujuan akhir. Pendidikan ditujukan untuk meningkatkan produktivitas dan kreativitas anak didik sehingga mampu melakukan perubahan dan menciptakan sesuatu yang baru.

Pada kenyataannya pendidikan daerah 3T (Terdepan, Terpencil dan Tertinggal) seperti Kabupaten Mahakam Ulu masih banyak permasalahan-permasalahan mengenai pendidikan akan tetapi tim peneliti tertarik membuat usulan penelitian Dosen Pemula dengan judul "Analisis model dan 
metode Pembelajaran Daerah $3 T$ (terdepan,terpencil dan tertinggal) Di Kabupaten Mahakam Ulu".

\section{RUANG LINGKUP}

Adapun ruang lingkup da cakupan dari penelitian ini adalah sebagi berikut:

\subsection{Cakupan Permasalahan}

Dalam cakupan permasalahan dalam penelitian ini, yaitu menganalisis model dan metode pembelajaran tepat guna di daerah $3 \mathrm{~T}$ (terdepan,terpencil dan tertinggal) pada kabupaten Mahakam Ulu?

\subsection{Batasan-Batasan Penelitian}

Adapun batasan dalam penelitian ini ialah untuk mengetahui model dan metode pembelajaran yang sesuai pada daerah 3T (terdepan,terpencil dan tertinggal) di kabupaten Mahakam Ulu .

\subsection{Rencana Hasil Yang Didapat}

Sedangkan untuk manfaat dalam penelitian ini adalah memberikan solusi dalam penerapan model dan metode pembelajaran yang tepat agar dapat meningkatkan mutu pendidikan yang berada pada daerah $3 \mathrm{~T}$ (terdepan,terpencil dan tertinggal) khusunya pada kabupaten Mahakam Ulu

\section{BAHAN DAN METODE}

Adapun bahan atau teori dalam penelitian ini yaitu sebagai berikut :

\subsection{Model Pembelajaran}

Dalam proses pembelajaran dikenal istilah model pembelajaran. Menurut (Intan, 2012) pembelajaran ialah pola yang digunakan sebagai pedoman dalam merencanakan pembelajaran di kelas maupun tutorial. Hal tersebut juga diungkapkan oleh Erman dalam (Erita, 2016 : 3) pembelajaran adalah pola interaksi siswa dengan guru didalam kelas yang menyangkut strategi, pendekatan, model dan metode dan teknik pembelajaran yang diterapkan dalam pelaksanaan kegiatan belajar mengajar di kelas Menurut Erman dalam (Erita, 2016 : 4), ada beberapa model pembelajaran yang dapat dijelaskan sebagai berikut : 1. Model Pembelajaran Kooperatif.

Pembelajaran kooperatif merupakan pembelajaran yang mengutamakan adanya kerjasama. Pembelajaran kooperatiff dikembangkan berdasarkan teori belajar kontruktivis. Sebagaimana yang dikemukakan oleh Johnson dan slavin dalam Slavin (2010) "'Struktur tujuan kooperatif menciptakan sebuah situasi dimana satu-satunya cara anggota kelompok bisa meraih tujuan pribadi. Mereka adalah jika kelompok mereka bisa sukses.

2. Model Pembelajaran Teman Sebaya.

Menurut Erman dalam (Erita, 2016) tutor sebaya adalah sumber belajar selain guru, yaitu teman sebaya yang lebih pandai memberikan bantuan belajar kepada 5 teman-teman sekelasnya disekolah. Sedangkan menurut (Oemar, 2001) tutor sebaya merupakan bimbingan pembelajaran dalam bentuk pemberian bimbingan, bantuan, petunjuk, arahan, dan motivasi agar siswa dapat efisiendan efektif dalam belajar..

\subsection{Metode Pembelajaran}

Menurut (Choiriyah, 2016) Metode pembelajaran adalah macam-macam pendekatan yang digunakan guru dalam interaksi dengan peserta didik (siswa), dalam proses pembelajaran yang menghasilkan perubahan sikap dan tingkah laku.

Dari pengertian di atas bisa disimpulkan bahwa model dan metode pembelajaran adalah cara yang digunakan oleh guru dalam menyampaikan materi pelajaran agar mudah dipahami oleh siswa.

Dalam menyampaikan materi pelajaran, seorang guru harus mampu menggunakan model dan metode yang baik dan benar karena ia menguasai tekniknya. Dalam (Erita, 2016) Adapun beberapa model dan metode dalam pembelajaran yang dapat dijelaskan sebagai berikut :

1. Metode Ceramah

Menurut (Wahyuni dan Baroroh , 2012) model dan metode ceramah adalah Komunikasi yang terjadi cenderung satu arah di mana alat komunikasi yang utama digunakan adalah berbicara. Karena komunikasi yang terjadi hanya satu arah, maka proses belajar mengajar menjadi kurang menarik bahkan membosankan. Meskipun demikian masih banyak yang tetap menggunakan model dan metode ceramah tanpa variasi lain. Selain itu menurut (Maisaroh dan Rostrieningsih, 2010) Ketika proses pembelajaran tersebut berlangsung, banyak siswa yang mengantuk atau mengobrol. Rasa ingin tahu siswa tidak terbangun, kemandirian dalam kegiatan pembelajaran pun sedikit sekali terlihat.

2. Metode Ekspositori.

Metode ekspositori sama seperti model dan metode ceramah dalam hal terpusatnya kegiatan. Tetapi pada model dan metode ekspositori dominasi guru banyak berkurang, karena tidak terus menerus berbicara. Pada model dan metode ekspositori siswa belajar lebih aktif dari pada model dan metode ceramah.

3. Model dan Metode Demontrasi.

Metode demontrasi sejenis dengan etode ceramah metode ekspositori. Kegiatan belajar mengajar berpusat pada guru atau guru mendominasi kegiatan belajar mengajar. Tetapi pada model dan metode demontrasi dominasi guru lebih berkurang lagi.

4. Metode Drill dan metode Latihan

Metode drill adalah suatu metode atau cara mengembangkan kompetensi atau skill anak didik baik dalam aspek kognitif, afektif maupun psikomotor, sehingga anak lebih terampil dalam bidang yang dilatihkan. 
5. Metode Tanya Jawab

Metode Tanya jawab adalah suatu cara penyajian bahan pelajaran melalui bentuk pertanyaan yang perlu dijawab oleh anak didik.

6. Metode Penemuan.

Pada model dan metode ini materi disampaikan hingga bentuk akhir, sedangkan cara belajar siswa merupakan belajar dengan menerima (Receptioning Learning). Pembelajaran dengan model dan metode penemuan berharap agar siswa benar-benar aktif belajar menemukan sendiri bahan yang dipelajarinya.

7. Metode Inkuiri.

Metode inkuiri adalah metode mengajar yang paling mirip dengan metode penemuan. Perbedaannya adalah dalam model dan metode penemuan hasil akhir yang harus ditemukan siswa merupakan sesuatu yang baru bagi dirinya, namun sudah diketahu oleh guru. Sedangkan dalam model dan metode inkuiri hal baru itu juga belum diketahui oleh guru.

\subsection{Metode Penelitian}

Dalam Penelitian ini menggunakan beberapa Metode Sebagai Beikut :

\subsubsection{Jenis Penelitian}

Metodologi yang digunakan dalam penelitian ini adalah model dan metode tindakan kelas. Penelitian tindakan kelas (PTK) atau yang lebih dikenal dengan classroom action research (CAR), pada prinsipnya model dan metode ini adalah untuk perbaikan dan peningkatan layanan professional pendidik dalam menangani proses belajar mengajar dengan melakukan berbagai tindakan alternatif dalam memecahkan persoalan pembelajaran. Dalam penelitian ini tim mencoba menemukan model dan metode pembelajaran dengan memanfaatkan masyarakat sekitar lokasi studi dengan latar belakang Sarjana Pendidikan yang telah tergabung dalam Forum Komunitas Guru 3T.

\subsubsection{Lokasi dan Waktu Penelitian}

Lokasi dalam penelitian ini adalah di Kabupaten Mahakam Hulu Ibu Kota Ujoh Bilang dengan subyek penelitian Pelaku dalam bidang pendidikan, dipilihnya Kabupaten Mahakam Hulu sebagai lokasi penelitian karena daerah Kabupaten Mahulu termasuk dalam kategori daerah $3 \mathrm{~T}$ (terdepan,terpencil dan tertinggal) sesuai dengan Perpres No.131 Tahun 2015 Tentang Daerah Tertinggal Tahun 2015 - 2019.

\subsubsection{Populasi dan Sampel}

Populasi dalam penelitian ini adalah Sekolah Negeri, Seperti Sekolah Dasar Negeri 1 (SDN 1) Ujoh Bilang Kelas VI , Sekolah Menengah Pertama Negeri 1 (SMPN 1) Ujoh Bilang Kelas VII dan Sekolah Menengah Pertama Negri (SMAN 1) Kelas X di Kabupaten Mahakam Hulu, sebanyak 90 responden yang terdiri dari beberapa Murid Sekolah (Rata-rata jumlah murid per Kelas \pm 30 siswa).

\subsubsection{Teknik Analisis Data}

Salah satu bagian penting dalam penelitian dengan analisis Penelitian Tindakan Kelas (PTK) adalah penelitian tindakan dengan dua aktivitas yang dilakukan secara simultan, yaitu aktivitas tindakan (action) dan aktivitas penelitian (research). Menurut (juwariyah,2019) Aktivitas belajar siswa sebatas pada aktivitas belajar yang diamati dalam penelitian, yaitu aktivitas bertanya, mendengarkan, menulis atau mencatat, membaca, mengeluarkan pendapat, diskusi, atau praktik, dan kedua terjadi peningkatan prestasi belajar siswa yang ditunjukkan dengan peningkatan nilai rata - rata, peningkatan jumlah siswa tuntas, dan peningkatan ketuntasan klasikal.

Mengingat penelitian ini merupakan penelitian tindakan yang dilaksanakan di dalam kelas, maka model dan metode yang digunakan dalam penelitian ini adalah metode Ceramah, metode Ekspositori, metode Demontrasi, metode Drill \& dan metode Latihan ,metode Tanya Jawab, metode Penemuan, dan metode Inkuiri. yang aka di jelaskan di bawah ini sebagai berikut :

Rancangan siklus penelitian ini menggunakan Kemmis dan Taggart. Prosedur kerja dalam penelitian tindakan menurut Kemmis \& Taggart dalam (Meisaroh \& Rostriningsih, 2010), meliputi 4 tahapan sebagai berikut :

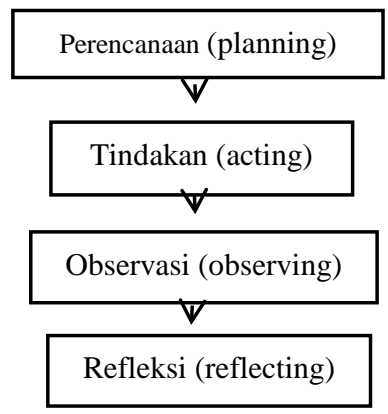

\section{Gambar 1. Tahapan Rancangan Siklus Penelitian}

Dalam siklus tersebut akan berulang terus sehingga membentuk spiral. Banyaknya siklus yang dilakukan tergantung pada peningkatan hasil belajar. Proses siklus akan berhenti pada saat siswa sudah mengalami peningkatan hasil belajar. Dalam penelitian ini, peneliti berencana untuk melakukan 2 - 3 kali siklus tindakan. Secara umum tahapan tindakan dalam masing-masing siklus penelitian adalah sebagai berikut:

1. Perencanaan

1) Mempelajari kurikulum pelajaran dan buku ajar untuk mempersiapkan bahan ajar dan membuat Rencana Pelaksanaan Pembelajaran (RPP). hal ini sesuai dengan Menurut (Yasyakur, 2017) Kepada guru-guru di sekolah khususnya pada matapelajaran kelas VI tema 5 tentang kewirausahaan, Kelas matematika diharapkan membuat Rencana Pelaksanaan Pembelajaran atau RPP sebagai pedoman dalam proses pembelajaran. 
2) Peneliti menyusun petunjuk teknis pelaksanaan kegiatan Active Learning tipe Quiz Team yang dilaksanaan pada pertemuan pertama dimulainya penelitian tindakan kelas.

3) Selama proses belajar mengajar berlangsung akan diterapkan variasi model dan metode Ceramah, model dan metode Ekspositori, model dan metode Demontrasi, model dan metode Drill model dan metode Latihan, model dan metode Tanya Jawab, model dan metode Penemuan model dan metode Inkuiri khususnya pada saat pelaksanaan penyampaian teori berlangsung.

4) Menyusun ringkasan materi yang akan diajarkan untuk setiap pokok bahasan.

5) Mempersiapkan soal-soal cadangan, sebagai antisipasi kemungkinan jika siswa tidak mempersiapkan soal.

2. Pelaksanaan Tindakan

1) Memberikan bahan ajar yang berkaitan dengan materi yang akan diajarkan dengan menerapkan pembelajaran kooperatif dan pembelajaran teman sebaya.

2) Menjelaskan skenario pembelajaran dan langkah langkah penerapan Quiz atau soal kepada siswa.

3) Memberikan materi dan sebelum menjelaskan materi, peneliti memberikan persepsi atau pemahaman terlebih dahulu kepada Siswa. Peneliti ingin mengetahui sejauh mana pemahaman siswa terhadap materi ajar dengan menggunakan beberapa model dan metode pembelajaran yang diajarkan oleh .

4) Peneliti mengevaluasi hasil kuis dan menilai perkembangan siswa selama pembelajaran dengan memperhatiakan dan menyesuaikan model dan metode pembelajaran yang telah berlangsung.

5) Selanjutnya, peneliti memberikan post test untuk mengetahui tingkat keberhasilan dari setiap kegiatan pembelajaran yang telah dilakukan di siklus pertama

3. Pengamatan / Observasi

Tahap observasi/ pengamatan merupakan tahap dimana peneliti mulai mendokumentasikan proses kegiatan pembelajaran, keadaan dan faktor-faktor lain yang timbul dan berkembang selama pelaksanaan tindakan. Hasil dari observasi tersebut dijadikan sebagai dasar melakukan refleksi dalam merencanakan tindakan selanjutnya. Selain itu juga mengamati situasi proses kegiatan pembelajaran berlangsung dan mendeskripsikan hal-hal yang terjadi dan menuliskannya pada lembar . Aspek utama yang dinilai adalah tentang perkembangan keaktifan siswa selama proses pembelajaran berlangsung.

\section{Refleksi}

Pada tahap ini peneliti secara kolaboratif bersama merenungkan dan mengevaluasi kembali, apakah rencana dengan pelaksanaan tindakan yang dilakukan berdasarkan hasil analisis terhadap data, proses dan apakah hasil pelaksanaan tindakan telah dilakukan dengan baik. Namun apabila terjadi kekurangan yang menyebabkan hasilnya tidak maksimal, maka diperlukan pengkajian ulang rencana untuk perbaikan hasil yang maksimal.

Hasil dari observasi dan refleksi pada siklus pertama akan menjadi dasar untu perencanaan tindakan pada siklus berikutnya sehingga tindakan pada masing-masing siklus akan berbeda sesuai dengan kekurangan pada siklus sebelumnya.

Perbedaan tersebut bisa berupa variasi soal dan tehnis pemberian kuis, penggunaan alat bantu, dan lain lain. Data yang digunakan dalam penelitian tindakan ini adalah data kuantitatif dan kualitatif. Analisis data kuantitatif digunakan untuk mengolah data setiap siklus berkaitan dengan prosentase kenaikan nilai hasil belajar. Analisis data kualitatif digunakan untuk menganalisis data dari hasil catatan lapangan dan catatan dokumentasi selama penelitian.

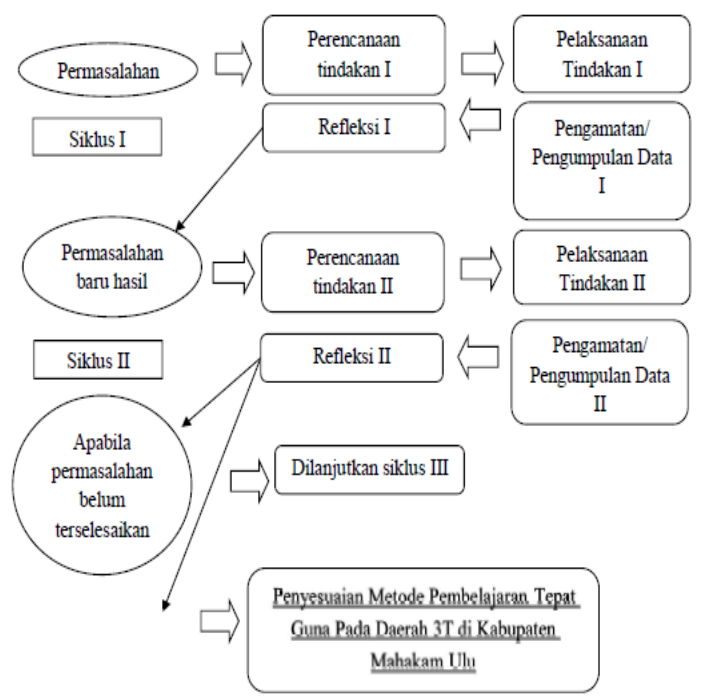

Gambar 2. Siklus I dan II Penelitian Tindakan Kelas (PTK) model dan metode Pembelajaran Tepa Guna Pada Daerah 3T di Kab. Mahakam Ulu

Penelitian ini dilaksanakan dalam dua siklus, dimana masing-masing siklus dilaksanakan satu kali pertemuan dengan alokasi waktu 1 X 35 menit dengan menggunakan Model Pembelajaran Kooperatif pada tiap Siklus I dan alokasi waktu 1 X 35 menit menggunakan Model Pembelajaran Teman Sebaya pada Siklus II. Penelitian ini dilaksanakan berdasarkan hasil observasi awal sebelum pelaksanaan tindakan yang menjadi pokok permasalahan dalam penelitian ini.

Langkah Pengembangan Instrumen penelitian yang digunakan adalah action receach atau tindakan yang dilakukan dalam bentuk spiral atau memutar ke arah bawah, rancangan penelitian yang digunakan sesuai 
dengan kaidah-kaidah penelitian dan tindakan dan disesuaikan dengan kondisi spesifik subjek penelitian serta kebutuhan pengukuran parameter penelitian. Penelitian tindakan ini dilakukan sebagai upaya perbaikan suatu praktik pendidikan melalui pemberian tindakan sebagai berikut:

1. Rancangan/perencanaan awal, sebelum mengadakan penelitian peneliti menyusun rumusan masalah tujuan membuat rencana tindakan, termasuk di dalamnya instrumen penelitian dan perangkat pembelajaran.

2. Pelaksanaan dan pengamatan, meliputi tindakan yang dilakukan oleh peneliti sebagai upaya pembangunan pemahaman konsep siswa serta mengamati hasil atau dampak dari diterapkankanya pembelajaran penemuam pembimbing.

3. Refleksi, penelitian mengkaji, melihat dan mempertimbangkan hasil atau dampak dari tindakan yang dilakukan berdaserkan lembar pengamatan yang di isi oleh pengamat.

4. Rancangan/rencana yang direvisi, berdasarkan hasil refleksi dari pengamat membuat rancangan yang direvisi untuk dilaksanakan pada siklus berikutnya.

Pelaksanakan ini dilaksanakan selama tiga siklus/ putaran. Observasi dibagi dalam tiga putaran, yaitu putaran 1, 2, dan 3 (jika dibutuhkan), dimana masing-masing putaran dikenai perlakuan yang berbeda-beda model dan metode dengan membahas satu sub bab pokok bahasan yang diakhiri dengan tes formatif di akhir masing putaran. Dibuat dalam 2 - 3 putaran dimaksudkan untuk memperbaiki sistem pengajaran yang dilaksanakan jika dirasa belum menemukan hasil yang maskimal.

\section{PEMBAHASAN}

Ketuntasan Proses Pembelajaran Siklus I dengan menggunakan model Pembelajaran Kooperatif dan metode Ceramah pada sekolah Dasar Negeri 1 (SDN 1) Ujoh Bilang Kelas VI sebesar $40 \%$ yang tuntas dan Siklus II sebesar 50\% hal ini berarti kenaikan ketuntasan dalam belajar hanya berkisar sebesar 10\%, sedangkan pada Sekolah Menengah Pertama Negeri 1 (SMPN 1) Ujoh Bilang Kelas VII dengan model dan metode ceramah pada siklus I dan II tidak ada perubahan yang cukup signifikan. berbeda dengan Sekolah Menengah Pertama Negri (SMAN 1) Ujoh Bilang Kelas Kelas X pada tahap siklus I sebesar $60 \%$ berubah pada siklus II menjadi $70 \%$ yang berarti hanya mengalami kenaikan $10 \%$ pada siklus ke II.

Pada model Pembelajaran Kooperatif dan metode Ekspositori pada sekolah Dasar Negeri 1 (SDN 1) Ujoh Bilang Kelas VI sebesar 60\% yang tuntas dan Siklus II sebesar $80 \%$ hal ini berarti kenaikan ketuntasan dalam belajar hanya berkisar sebesar 20\%, sedangkan pada Sekolah Menengah Pertama Negeri 1 (SMPN 1) Ujoh Bilang Kelas VII sebesar $80 \%$ yang tuntas dan Siklus II sebesar $90 \%$ hal ini berarti kenaikan ketuntasan dalam belajar hanya berkisar sebesar $10 \%$ berbeda dengan Sekolah Menengah Pertama Negri (SMAN 1) Ujoh Bilang Kelas Kelas X pada tahap siklus I sebesar 90\% berubah pada siklus II menjadi $70 \%$ yang berarti hanya mengalami kenaikan $100 \%$ pada siklus ke II yang berarti model Pembelajaran Kooperatif dan metode pembelajaran Ekspositori sangat tepat untuk di kembangkan di ekolah Menengah Pertama Negri (SMAN 1) Ujoh Bilang Kelas Kelas X khususnya dalam mata pelajaran Matematika.

Model Pembelajaran Kooperatif dan metode Demontrasi merupakan model dan metode pengajaran dengan memperagakan kepada peserta didik dalam hal ini pada sekolah Dasar Negeri 1 (SDN 1) Ujoh Bilang Kelas VI sebesar $90 \%$ yang tuntas dan Siklus II sebesar $100 \%$ hal ini berarti kenaikan ketuntasan dalam belajar hanya berkisar sebesar $10 \%$ yang berarti dalam model dan metode demonstrasi perserta didik sangat menikmati dan cocok untuk di terapkan sama dengan Sekolah Menengah Pertama Negeri 1 (SMPN 1) Ujoh Bilang Kelas VII sebesar $90 \%$ yang tuntas dan Siklus II sebesar $100 \%$ hal ini berarti kenaikan ketuntasan dalam belajar hanya berkisar sebesar $10 \%$ yang berarti sangat tepat untuk dikembangkan di wilayah tersebut untuk di aplikasikan pada wilayah-wilayah yang dianggap sejih oleh peneliti, berbeda dengan Sekolah Menengah Pertama Negri (SMAN 1) Ujoh Bilang Kelas Kelas X pada tahap siklus I sebesar $90 \%$ tidak berubah pada siklus II tetap $90 \%$ yang berarti tidak mengalami perubahan yang signifikan.

Dalam model Pembelajaran Kooperatif dan metode drill para peserta didik sepertinya mengalami perubahan yang tidak baik mengingat model dan metode drill lebih memberikan latihan-latihan sehingga para perserta didik sepertinya tidak cocok hal ini dapat dilihat pada beberapa penjelasan pada sekolah Dasar Negeri 1 (SDN 1) Ujoh Bilang Kelas VI sebesar 0\% yang tuntas dan Siklus II sebesar $10 \%$ hal ini berarti kenaikan ketuntasan dalam belajar hanya berkisar sebesar $10 \%$ yang berarti dalam model Pembelajaran Kooperatif dan metode drill bagi perserta didik sangat tidak ocok untuk di terapkan sama dengan Sekolah Menengah Pertama Negeri 1 (SMPN 1) Ujoh Bilang Kelas VII sebesar $10 \%$ yang tuntas dan Siklus II sebesar $100 \%$ hal ini berarti kenaikan ketuntasan dalam belajar hanya berkisar sebesar $30 \%$ yang berarti tidak tepat untuk dikembangkan di wilayah tersebut sedangkan Sekolah Menengah Pertama Negri (SMAN 1) Ujoh Bilang Kelas Kelas X pada tahap siklus I sebesar 20\% tidak berubah pada siklus II tetap 20\% yang berati tidak ada perubahan yang berpengaruh untuk pengambangan pendidikan di wilayah tersebut.

Sedangkan model Pembelajaran Kooperatif dan metode tanya jawab merupakan model dan metode yang bisa dikatakan tidak ada perngaruh sama sekali ini dapat dilihat pada sekolah Dasar Negeri 1 (SDN 1) Ujoh Bilang Kelas VI sebesar $40 \%$ yang tuntas dan Siklus II sebesar $40 \%$ hal ini berarti kenaikan ketuntasan dalam belajar hanya berkisar sebesar $0 \%$ atau dapat dikatakan hanya beberapa peserta didik saja yang mampu berinteraksi sedangkan perserta yang lain hanya mengikuti saja, sedangkan pada Sekolah Menengah Pertama Negeri 1 (SMPN 1) Ujoh Bilang Kelas VII dengan model Pembelajaran Kooperatif dan metode 
ceramah pada siklus I sebesar 39\% dan II menjadi $40 \%$ kenaikan perubahan hanya sekitar $10 \%$ saja dikarenakan para perserta didik merasa takut dan malu jika tidak bisa menjawab. berbeda dengan Sekolah Menengah Pertama Negri (SMAN 1) Ujoh Bilang Kelas Kelas X pada tahap siklus I sebesar $60 \%$ berubah pada siklus II menjadi $60 \%$ yang berarti hanya mengalami kenaikan $0 \%$ pada siklus ke II dikarenkan banyak peserta didik hanya itu-itu saja orang yang mampu melaksakan model Pembelajaran Kooperatif dan metode ini karena pada dasarnya model Pembelajaran Kooperatif dan metode tanya jawab untuk mata pelajaran matematika sangat tidak cocok di terapkan karena harus dilakukan demonstrasi langsung di depan kelas.

Dalam melaksanakan model Pembelajaran Kooperatif dan metode penemuan ada beberapa permasalahan jika di terapkan pada daerah $3 \mathrm{~T}$ Karena minimnya sarana dan prasarana sehingga untuk di terapkan pada beberapa sekolah di wilayah $3 \mathrm{~T}$ sangat sulit sehingga peneliti membuat pola yang sederhana seperti mata pelajaran untuk SD yaitu tema 5 tentang kewiraushaan, kemampuan peserta didik sekolah Dasar Negeri 1 (SDN 1) Ujoh Bilang Kelas VI sebesar $10 \%$ yang tuntas dan Siklus II sebesar $10 \%$ hal ini berarti kenaikan ketuntasan dalam belajar hanya berkisar sebesar $0 \%$ yang berati tidak ada perubahan yang baik untuk diterapkannya model dan metode tersebut, sedangkan pada Sekolah Menengah Pertama Negeri 1 (SMPN 1) Ujoh Bilang Kelas VII dengan model dan metode ceramah untuk mata pelajaran matematika pada siklus I sebesar 10\% dan siklus II menjadi 30\% atau kenaikan sebesar $20 \%$ yang berarti tidak ada perubahan yang cukup signifikan sedangkan Sekolah Menengah Pertama Negri (SMAN 1) Ujoh Bilang Kelas Kelas X pada tahap siklus I sebesar $10 \%$ berubah pada siklus II menjadi $70 \%$ yang berarti hanya mengalami kenaikan $20 \%$ pada siklus ke II, hal ini menujukan bahwa model dan metode penemuan kurang cocok untuk di terapkan pada wilayah tersebut.

Dalam model dan metode inkuri peserta didik di tuntut untuk aktif dalam proses penemuan dan siswa lebih domininan untuk belajar sendiri yang berakibat fatal dalam diterapkannya dilakukan pada wilayah 3T hal ini dapat dibuktikan pada sekolah Dasar Negeri 1 (SDN 1) Ujoh Bilang Kelas VI hanya sebesar $10 \%$ yang tuntas dan Siklus II sebesar $10 \%$ hal ini berarti tidak ada perubahan yang berarti dalam model dan metode inkuri perserta didik tidak cocok untuk di terapkan, sama dengan Sekolah Menengah Pertama Negeri 1 (SMPN 1) Ujoh Bilang Kelas VII sebesar $10 \%$ yang tuntas dan Siklus II sebesar $10 \%$ hal ini berarti kenaikan ketuntasan dalam belajar hanya berkisar sebesar $0 \%$ yang berarti sangat tidak tepat untuk dikembangkan di wilayah tersebut tidak jauh berbeda pada Sekolah Menengah Pertama Negri (SMAN 1) Ujoh Bilang Kelas Kelas X pada tahap siklus I sebesar $10 \%$ tidak berubah pada siklus II tetap $10 \%$ yang berarti sama dikarenakan model dan metode inkuri sendiri banyak menepatkan peserta didik untuk menemukan sendiri dan belajar sendiri sehingga tidak cocok untuk di terapkan di wilayah $3 \mathrm{~T}$ dimana masih minim infrastruktur sarana dan prasarana sekolah selain itu terbatasnya akses informasi seperti internet dan telekomunikasi sehingga tingkat kemampuan peserta didik dalam memahami mata pelajaran di sekolah sangatlah sulit dibandingkan dengan sekolah-sekolah yang berada di perkotaan.

\section{KESIMPULAN}

Hasil observasi awal pada Sekolah Dasar Negeri 1 (SDN 1) Ujoh Bilang Kelas VI mata pelajaran tema 5 tetang kewiraushaan, Sekolah Menengah Pertama Negeri 1 (SMPN 1) Ujoh Bilang Kelas VII mata pelajaran matematika dan Sekolah Menengah Pertama Negri (SMAN 1) Kelas X terhadap hasil belajar Matematika sebelum dilaksanakannya penelitian tindakan kelas (PTK) dengan pendekatan pembelajaran luas persegi dan persegi panjang diperoleh rata-rata hasil belajar individu sebesar diperoleh hasil observasi awal dari 30 orang siswa, 18 orang siswa yang belum tuntas pembelajarannya atau diperoleh $60 \%$ untuk siswa tingkat SD sedangkan tingkat SMP dari 30 orang siswa, 21 orang siswa yang belum tuntas pembelajarannya atau diperoleh $70 \%$, sementara yang telah tuntas hasil belajar sebanyak 9 orang siswa dan dinyatakan tuntas atau sebesar $30 \%$ pada tingkat SMA dari 30 orang siswa, 12 orang siswa yang belum tuntas pembelajarannya atau diperoleh $40 \%$, sementara yang telah tuntas hasil belajar sebanyak 18 orang siswa dan dinyatakan tuntas atau sebesar $60 \%$.

Hasil Belajar sekolah Dasar Negeri 1 (SDN 1) Ujoh Bilang Kelas VI dengan model Pembelajaran Kooperatif dan metode demonstrasi mempengaruhi sebesar 90\% yang tuntas dan Siklus II sebesar $100 \%$ hal ini berarti kenaikan ketuntasan dalam belajar hanya berkisar sebesar $10 \%$ yang berarti dalam model Pembelajaran Kooperatif dan metode demonstrasi perserta didik sangat tepat untuk di terapkan ketepatan itupun sama dengan Sekolah Menengah Pertama Negeri 1 (SMPN 1) Ujoh Bilang Kelas VII sebesar 90\% yang tuntas dan Siklus II sebesar 100\% sehingga dapat dikatakan model Pembelajaran Kooperatif dan metode demontrasi sangat cocok untuk diterapkan di SD dan SMP di daerah 3T sedangkan model dan metode Ekspositori pada Sekolah Menengah Pertama Negri (SMAN 1) Ujoh Bilang Kelas Kelas X pada tahap siklus I sebesar $90 \%$ berubah pada siklus II menjadi $70 \%$ yang berarti hanya mengalami kenaikan $100 \%$ pada siklus ke II yang berarti model dan metode pembelajaran Ekspositori sangat tepat untuk di kembangkan di ekolah Menengah Pertama Negri (SMAN 1) Ujoh Bilang Kelas Kelas X khususnya dalam mata pelajaran Matematika.

Aktivitas siswa sekolah Dasar Negeri 1 (SDN 1) Ujoh Bilang Kelas VI dalam pembelajaran tema 5 tetang kewirausahaan Matematika dengan menggunakan penerapan model Pembelajaran Kooperatif dan metode drill, Inkuri dan Penemuan sangat tidak cocok hal ini dapat dilihat pada siklus I dan II yang dimana hampr tidak perubahan yang signifikan hal ini juga sama dengan Sekolah Menengah Pertama Negeri 1 (SMPN 1) 
Ujoh Bilang Kelas VII mata pelajaran matematika untuk model Pembelajaran Kooperatif dan metode drill, Inkuri dan Penemuan tidak cocok yang dapat dilihat pada sikuls I dan II. Senada dengan Sekolah Menengah Pertama Negri (SMAN 1) Kelas $X$ terhadap hasil belajar Matematika yang dimana model dan metode yang tidak cocok ialah model dan metode inkuri di karenakan minimnya infrastrukrur sarana dan prasarana pendidikan di sekolah tersebut terutama akses internet dan telekomunikasi

\section{SARAN}

Pembelajaran Pendidikan yang selama ini hanya menggunakan strategi dan model dan metode yang sudah ada, diperlukan upaya guru untuk merancang dan mendesain model Pembelajaran Kooperatif dan metode pembelajaran yang inovatif, efektif, bermakna dan menyenangkan untuk siswa.

Salah satu model dan metode yang dapat digunakan dalam meningkatkan hasil belajar siswa pada mata pelajaran adalah melalui penerapan model dan metode pembelajaran demonstrasi dan juga Ekspositori dan juga tidak menutup kemungkinan dengan model dan metode-model dan metode lain yang sejenis yang disesuaikan sehingga para perserta didik mampu menyerap ilmu pendidikan sama dengan peserta didik yang berada diwilayah perkotaan.

Diharapkan sarana dan prasaran infrastruktur sekolah sama dengan yang ada diperkotaan agar kedepanya permaslahan terutama kesenjangan dalam menerima informasi minimal sama dengan wilayah perkotaan sehingga peningkatan khususnya pendidikan pada daerah 3 $\mathrm{T}$.

\section{DAFTAR PUSTAKA}

Besse Intan Permatasari.2014.Efektivitas Penerapan Pembelajaran Superitem Dalam Meningkatkan Pemahaman Konsep Matematika Siswa Kelas $X$ SMAN 11 Makassar. Jurnal Matematika dan Pembelajaran Volume 2, Nomor 1. Fakultas Tarbiyah dan Keguruan UIN Alauddin Makassar

Choiriyah, annisa'i. 2016. Pembelajaran Pengalaman Langsung Dalam Meningkatkan Pembelajaran Pendidikan agama islam dan budi pekerti. jurnal Nur el-islam, volume 3, nomor 2

Daru Wahyuni dan Kiromim Baroroh.2012. Penerapan model dan metode Pembelajaran Simulasi Untuk Meningkatkan Aktivitas Dan Prestasi Belajar Ekonomika Mikro. Jurnal Ekonomi \& Pendidikan, Volume 9 Nomor 1.Universitas Negeri Yogyakarta

Erita, Selvia.2016.Beberapa, Pendekatan, Strategi, model dan metode Dalam Pembelajaran Matematika.jurnal ilmu pendidikan vol. Vol 1 No 2.IAIN.Riau

Maisaroh dan Rostrieningsih. 2010. Peningkatan Hasil Belajar Siswa Dengan Menggunakan model dan metode Pembelajaran Active Learning Tipe Quiz Team Pada Mata Pelajaran Keterampilan Dasar
Komunikasi di SMK Negeri 1 Bogor. Jurnal Ekonomi \& Pendidikan, Volume 8 Nomor 2

Oemar, Hamalik. 2001. Pendekatan Baru strategi Belajar Mengajar Berdasarkan CBSA. Bandung: Sinar Baru Algesindo Slavin, Robert E. 2010. Cooperative Learning: Teori Riset dan Praktik. Bandung: Nusa Media

Juwariyah, Siti. 2019. Peningkatan Aktivitas dan Prestasi Belajar Siswa melalui Penerapan model dan metode Pembelajaran Kooperatif Group Investigation . Jurnal Pendidikan

Madrasah, Volume 3, Nomor 1. Madrasah Tsanawiyah Negeri I Bantul

Supriatna,Usep. 2016. Pengembangan Pembelajaran Komprehensif Dalam Pendidikan Ilmu Pengetahuan Sosial di Sekolah Dasar.Jurnal Inovasi Pembelajaran, Volume 2, Nomor 1. FKIP Universitas PGRI Ronggolawe Tuban

Yasyakur, Moch. 2017. Efektivitas Pembelajaran Karakter Pada Matapelajaran Ektrakulikuler di Sekolah Full Day School. Jurnal Edukasi Islami Jurnal Pendidikan Islam Vol. 06 No.12.STAI Al-Hidayah Bogor

\section{UCAPAAN TERIMAKASIH}

Riset Penulis dibayai oleh Hibah Penelitian Dosen Pemula dari KEMENRISTERKDIKTI dengan Kontrak No. 599/L11/KM/2019, tanggal 19 Februari 2019 